2016, volume 5, issue 2

Murawski, T. (2016). Corporate Social Responsibility in Japanese banking sector. Copernican Journal of Finance \& Accounting, 5(2), 149-161. http://dx.doi.org/10.12775/CJFA.2016.020

\author{
Tomasz Murawski* \\ Nicolaus Copernicus University
}

\title{
CORPORATE SOCIAL RESPONSIBILITY \\ IN JAPANESE BANKING SECTOR
}

Keywords: corporate social responsibility, bank, banking sector, reporting.

J E L Classification: G21, M14, G15.

Abstract: The concept of CSR is developed in the theory of economics and management from the 50 s of the last century. In practice, the banking industry uses it for many years. The evolution of the banking sector caused the emergence of new services and products that are integrated with the philosophy of CSR. In Japan, each of the bank you can see the relationship between business, society and the environment. This activity follows the tradition and adopted a philosophy that is both fostered and developed. Article will present examples of major Japanese banks on this plane.

\section{INTRODUCTION}

Over the recent years Corporate Social Responsibility (CSR) has become a new concept for the banking sector. Community particularly gives the pressure to rebuild areas in which banks operate. The objective of this paper is to show how banking sector in Japan identify CSR. This term is in Asia wide recognized and for many years enterprises implemented in own activity the best practices in this area. The last crises temporarily upset the market, but CSR and report-

Date of submission: November 27, 2016; date of acceptance: January 15, 2017.

* Contact information: murawski.tomasz@gmail.com, Faculty of Economic Sciences and Management, Nicolaus Copernicus University, Gagarina 13a, 87-100 Toruń, Poland, phone: +48 889307510 . 
ing about the responsibility becomes the standard practice. However present time banks recognize the importance of assuring non-financial information in reporting. All of the world's largest banks and over $80 \%$ of smaller banks are reporting on corporate responsibility. (KPMG 2016) This trend has also been touched Japan. Article included the positive examples, however the author, in aim of objective look on data it will bring up also negative aspects of this activity. This article presents a view about relationship between Corporate Social Responsibility principles and application by the largest banks in Japan.

\section{THE RESEARCH METHODOLOGY AND THE COURSE OF THE RESEARCH PROCESS}

In this article the author attempts to describe experience of the Japanese banks in CSR and with all aspects relating to it. This study will first present the wide concept and data of corporate responsibility activity on financial market in Japan. The theoretical analysis is based on then currently sustainability reports, global reports of international organizations, which take care subject-matter of social responsibility, sustainable development or ethics. Additionally, were analyzed products of banks in the context of coherence with the spirit of CSR. Next it will present the comparison of the Japanese and world main growth indicators and the numbers of CSR reports. This analysis will allow to verify the hypothesis of no long-term impact of the crisis on activity in the area of CSR reporting.

\section{CSR IN JAPAN}

There are however differing views on how CSR is viewed by several countries and/or companies. Although the functioning of the term CSR for many years, in various parts of the world there are a variety of its origin. In Japan social responsibility is strongly associated with the concept of Sanpo Yoshi. (Takahashi, 2009) This philosophy literally means "three-way satisfaction". This satisfaction refers to the three dimensions: sellers, buyers and society. Nowadays any Japanese company positioned its CSR policy to these three areas. This approach is consistent with the classical model of CSR, which involves four impact areas: market, environment, employee, company (Murawski, 2009). However, differences resulting from the approach not to affect the perception of a similar impact corporate social responsibility activities. 
Scheme 1. Types of areas in Sanpo Yoshi and classical model o CSR

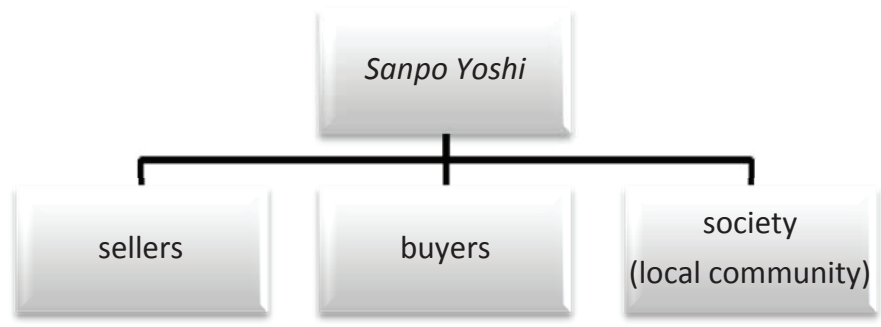

S o u r c e : own work based on: Takahashi, 2009, pp. 107-118.

The all philosophy Sanpo Yoshi is closed in one message, that merchant from 18. Century Jihei Nakamura, has got describe in own essay to his grandchild (Japan's Policy for CSR, 2012, p. 1): “When you go abroad to do business, it is most important to always keep in mind:

- To make sure that the garments you are selling satisfy all customers in that country;

- Think and act customers first;

- Never aim for a short term high profit;

- Be humble that you are dependent on God's blessing;

- Do business with a caring mind for the people in the region;

- Never lose faith in God in order not to have a malicious mind.

By so doing, you are in line with reason and will be able to keep a healthy body and mind." These words are the essence of the Japanese approach to CSR.

Many years have passed since the inception of these words. A lot has changed in that time. The change also underwent approach to corporate social responsibility. Various crises caused temporary disturbances on the market. Currently, the concept of CSR has strong support of government. Key players to promote CSR in Japan are (Japan's Policy for CSR, 2012, pp. 5-14):

- The Ministry of Economy, Trade and Industry - he is as CSR leader and is responsible for internal control, compliance with regulations and risk management, improvement of corporate competitiveness, human resources and corporate brands, and mostly for the promotion of CSR.

- The Cabinet Office created Report by the Study Group on Social Responsibility for a Safe and Comfortable. Sustainable Future.

- The Ministry of the Environment and Ministry of Health, Labor and Welfare - they are responsible for all cases in labor and environment areas. 
These public authorities are the authors of Environmental Report Guideline and Interim Report by the Study Group on the Way of CSR in Labor.

A lot of work that has gone into education about CSR, were squandered, because some slogans were devalued. The meaning of social responsibility concept is still not well understood by the corporate management. They try to implement a lot of initiatives under then CSR banner and part of these activities is only PR strategies. Responsible business leaders support long-term projects about sustainability (Ushijima, 2016).

Figure 1. Number of reports of companies from Asia region and only from Japan submitted to GRI

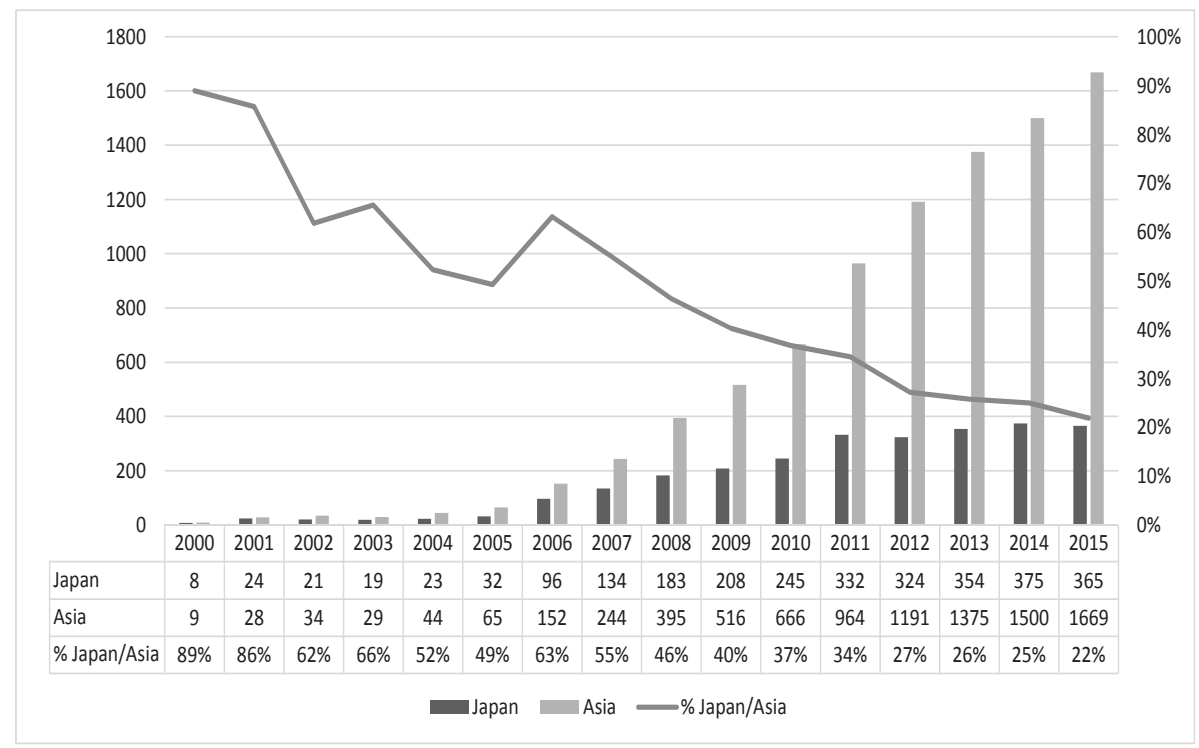

S o u r c e : own work based on: GRI Research data, 2016.

One of the levels of engagement in CSR is reporting and measuring of engagement. Companies build shareholder value in long-term perspective by engaging with stakeholders and by taking the impact of business on the society and environment. Japan since the beginning of the publication of the report $\mathrm{KPMG}^{1}$ was the leader, not only in Asia area, but also worldwide (KPMG, 2015).

1 “The KPMG Survey of Corporate Responsibility Reporting" is published since 1993. Till 2015 was nine edition of the report. 
The analysis of reports (e.g. Global Reporting Initiative (GRI)) allow for a conclusion that the trend of the share of published reports is satisfactory. Although the number of reports does not grow significantly, but it should be noted, that Japan started as the leader and the for several years remaining Asian countries have begun to develop in this area. Recent data indicate that $22 \%$ of reports in 2015 from the Asian region was published by Japanese companies (GRI Research data, 2016).

\section{BANKING SECTOR IN JAPAN}

Japanese banking system has a specific structure. On the top of the system is a Bank of Japan (BoJ) as a central bank, which was founded in 1882. The Bank operates under the "Bank of Japan Act" and it has placed two tasks: to achieve price stability and guarantee the stability of the financial system (BoJ Annual Review, 2016).

Scheme 2. Banking system in Japan

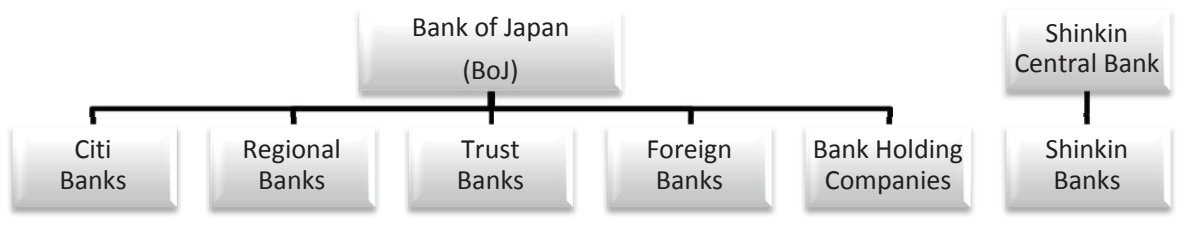

S o u r c e : own work based on: Financial Services Agency, 2016.

The banking system, except central bank, included also Citi Banks, Regional Banks, Trust Banks, Foreign Banks, Bank Holding Companies and Shinkin Banks. The Citi Banks are group of 4 megabanks: Mizuho Bank,Ltd., Sumitomo Mitsui Banking Corporation, The Bank of Tokyo-Mitsubishi UFJ,Ltd. and Resona Bank, Ltd.. Their task is to finance large companies and activity on the international financial market. Regional Banks is a group of more than 100 institutions across the country. Their target group is small and medium-sized enterprises and individual customers. As the name implies focus their business on local markets. The next member of Japanese banking system is Trust Banks. Trust bank is an institution which offer a wide investment and banking services to corporate and individual customers. Currently there are 16 banks with the above profile. In Japan also they have branches Foreign Banks. According 
to data for October 2016 there were a total of 53 banks from 25 countries. Another participant is the Bank Holding Companies, or 20 companies that have in its portfolio one or more banks. The last but not least group are Shinkin Banks. They are cooperative regional institutions that offer products to small and medium enterprises and local community and they've got own central bank Shinkin Central Bank. (Financial Services Agency, 2016).

Table 1. Top 10 Banks in Japan

\begin{tabular}{|c|l|c|}
\hline \hline Rank & \multicolumn{1}{|c|}{ Company } & Total assets on 30.06.2016 in US\$b \\
\hline \hline 1 & Mitsubishi UFJ Financial Group & 2901340 \\
\hline 2 & Japan Post Bank & 2022020 \\
\hline 3 & Mizuho Financial Group & 1923720 \\
\hline 4 & Sumitomo Mitsui Financial Group & 1764690 \\
\hline 5 & Norinchukin Bank & 999623 \\
\hline 6 & Sumitomo Mitsui Trust Holdings & 580308 \\
\hline 7 & Resona Holdings & 451283 \\
\hline 8 & Concordia Financial Group & 177295 \\
\hline 9 & Fukuoka Financial Group & 172537 \\
\hline 10 & Chiba Bank & 134658 \\
\hline \hline
\end{tabular}

S o u r c e : Banks in Japan, 2016.

In the history of the Japanese banks listed are manifold turbulence. There were periods of prosperity, but also a time a speculative bubble, as in the $90 \mathrm{~s}$ of the twentieth century. After years of crises and restructuring of the banking sector once again has created large organizations at various levels. An interesting phenomenon that takes place since 1990, is the system of M\&A in the banking. The crisis has contributed to the formation of large universal banks, and the government rescue program supported M\&A in banking sector (Miklaszewska, 2012).

\section{SOCIAL RESPONSIBILITY OF JAPANESE BANKS}

Mitsubishi UFJ Financial Group (MUFG) is the largest banking group in Japan. The history of the group dates back to 1880 and over the years was associated 
with mergers and acquisitions, not only in the banking market. Size does not bother them to put not only the financial targets but also CSR goals. In the business plan for the years 2016-2017 entered into a vision, which is also a medium-long term target "Be the world's most trusted group". This corporate vision and Principles of Ethics and Conduct make up the perception of CSR in the company. Before they can be discussed further actions and initiatives in this field, should indicate a very strong relationship management, organization structure and the structure of CSR. Mitsubishi UFJ Financial Group has established the Corporate Social Responsibility Committee. The main task is to promote Group-wide CSR activities (MUFG, 2016a).

MUFG operates in many areas of corporate social responsibility. First of example is customers' area. MUFG implements a quality management and monitoring customer feedback. Bank wants to know the customer feedback at every stage of the operation of the product or service. At the same time as creating new services to be the most customer-oriented and responsive to his suggestions. By making branches barrier-free, the MUFG Group is opening to elderly and the disabled (MUFG, 2016a).

Another area is community. MUFG is the initiator of Global Volunteer Month, and is engaged in CSR activities in every part of the world. Additionally, leads educational activities in the field of finance and ecology through cooperation with schools, universities and foundations. Simultaneously MUFG is engaged in social contribution activities through collaboration with The Organization for Industrial, Spiritual and Cultural Advancement-International (OISCA). The training concern ae. about sustainable organic farming techniques (MUFG, 2016a).

The next area is human resource strategy. The strategy describes a lot of possibilities for activities that are aimed at good employee. One example is the widely understood work life balance, which manifests itself in two approaches: child care and medical care. Another example is the hiring of people with disabilities or caring for equality in filling management positions (MUFG, 2016a).

The last but not least initiative is Responsible Finance. In this area, MUFG group offers a wide range of support. One of the activities are project finance that focus on renewable energy sources and new know-how. Bank of TokyoMitsubishi UFJ arranged 35 billion yen in project financing for Solar Power Generation Project in Miyazaki Prefecture. The power plant will have a total generation capacity of $96.2 \mathrm{MW}$, which helps to provide power to 30000 Japanese households a year. Engaging in green-activities MUFG was ranked No. 2 in the 
global project finance lead arranger table for renewable energy. MUFG actively promotes public-private financial partnerships that leverage subsidies and other national government support programs. Bank of Tokyo-Mitsubishi UFJ offers subsidized loans, which can be used for different purposes: promotion of upgrading facilities to improve energy efficiency, for the Purchase of EnergyEfficient Ships (to the use of high-efficiency diesel engines) or for another green projects, an example reducing C02. In 2015, there were 21 such projects, which together contributed to a reduction of 250,000 tons of CO2, and the economic dimension of these actions has been calculated at 5.5 billion yen. The next type of responsible financial engagement is ESG Investment (investment management that focuses on the environment, society, and governance) and Green Bonds. Mitsubishi UFJ Trust and Banking began offering customers investing in companies with clear social responsibility policies and programs and strong corporate governance systems. This strategy allows to increase returns over the medium- to long-term. The whole operation contributes to reducing the risk (MUFG, 2016a).

The last idea, which launched on September 2016 is MUFG Grenn Bond Initative. MUFG's green bond will be used to finance projects focused on the generation of renewable energy, specifically solar and wind energy (MUFG, 2016b). This initiative confirms that in today's financial world increasingly recognized the creation of green products and services (Dziawgo, 2014).

To be objective it should be noted that within the group there is also not glorious information. The Bank of Tokyo-Mitsubishi UFJ in 2013 and 2014 take a role in routing payments for Iranian customers through the New York branch. It was in violation of United States sanctions. First settlement was reached for $\$ 250$ million and second form $\$ 315$ million. In the matter involved it was also one of the audit firm PricewaterhouseCoopers (Protess, Silver-Greenberg, 2014).

Sumitomo Mitsui Financial Group (SMFG) is an example of a company that the main objective of the company is committed to the good, the good of the country and welfare of the region. The vision of the company is included in the sentence: "becoming the highly trusted global financial group which leads Japan and Asia, and grow along with clients" (SMFG, 2015, p. 6). The CSR strategy group entered into new priorities, which is to be areas of action for the next 10 years. The new themes: Environment, Next Generation and Community, are the three pillars of socially responsible activity of the company and at the same time they are related to the GRI reporting (SMFG, 2015). 
First is the approximate topics in the field of environment. The main goal is to promote of environmental management integrated with business. In Sumitomo Mitsui Financial Group is an Environmental Management System (EMS). SMFG has developed the organizational structure to promote EMS, because the major companies of group operating system based on ISO 14001 Certification. Another factor is to reduce the impact of group's activities on the environment. In this area, there have been many initiatives that can be classified as working of eco-office. One of the head buildings - SMBC East Tower - underwent the following improvements: utilization and preservation of nature, implementation of highly efficient systems, reduction of adverse environmental effects and creation of a sustainable building. These solutions expected to reduce approximately 35\% of $\mathrm{CO} 2$ emission. Another improvement is the use of solar panels in the IT centers. Solar will become independent at peak power shortages of conventional energy suppliers. An important process from the point of view of the department of credit is the management of environmental risks. At the time of analysis, the bank will determine the how big the impact on the environment will have the loan requested and the result this survey will have an impact on credit decisions. The last part of environmental activity is promotion of environmental businesses. In this area can be divided into several streams. The first is to develop financial solutions to support green investments. The Bank has in the product offer several types of eco-loans. The result of the investment is supporting clients' activities of ESG dimensions. Another example may be the first in Japan mobile hydrogen station. This innovative idea is a sample of an initiative using renewable energy. Another example is the introduction of a credit card with the socially contributing "Chikyuni Yasashii Card". It consists in the fact that with each transaction the Bank will provide part of the funds for environmental organizations with their own funds (SMFG, 2015, pp. 16-20).

The second pillar is the next generation. It is based on the broader HR strategy. One of the components is support for next generation asset inheritance and business succession. It manifests itself ensuring nursing and medical care or financial support for health care facilities. Another area where he developed the strategy of CSR in terms of generational aspect is contribution as a financial institution to emerging countries and Contribution to raising the level of financial literacy. These two purposes, although they are different in the core are convergent approach. In both cases, you have to go outside the company to the people. It does not matter whether it is a school, in order to improve the knowl- 
edge, or any other country that by branches can know the true face of CSR. The Group also draws attention to the work life balance (SMFG, 2015, pp. 22-26).

The last pillar is Community. In 2014, SMFG main activities in this area were related to the removal of the effects of the Great East Japan Earthquake. For this purpose was established special "Great East Japan Earthquake Support Fund". Donations to this fund was set at 400 yen from each employee's monthly salary. In addition, since May 2012 more than 700 employees SMFG took part in regular voluntary action in areas affected by the earthquake. An interesting initiative of the discussed area is the cooperation with Non-Government Organizations (NGO) and Non-Profit Organizations (NPO). SBMC created a fund where employees can transfer part of their salary. Then money are transferred from SMBC Volunteer Fund to more than 30 organizations for their statutory objectives. Another form of assistance is channeling funds through Sumitomo Mitsui Card to UNICEF, UNESCO, the World Wildlife Fund Japan and the World Food Program. The total amount of donations in 2014 amounted to almost 8 million yen (SMFG, 2015, pp. 27-30).

The confirmation of a practical approach to CSR in the field of finance at Sumitomo Mitsui Financial Group is the practice of socially responsible investment (SRI). It manifests itself not only in the possession in portfolio relevant products, but also participation in the SRI indices (FTSE4Good Global Index, FTSE4Good Global 100 Index, ESI Excellence Global) (SMFG, 2015, p. 35).

\section{THE COMPARISON OF CRISIS AND TURBULENCE IMPACT ON JAPANESE AND WORLDWIDE SUSTAINABILITY REPORTING}

The last 15 years in economy has been marked by the crisis, which began in 2008. These developments have had an impact on every level of activities of enterprises. Economic growth is one of the indicators that will be used in the analysis. Japan comparison on the background the whole world will illustrate the impact of the crisis on the analyzed market. The additional indicator, which will serve as a reference is a stock market index for the Tokyo Stock Exchange - Nikkei225. Analysis of these quotations will enable the observation of market sentiment. You may have noticed two periods collapse of 2000-2002/1H2003 and 2007/2008-2009. 
Figure 2. GDP growth (annual \%) 2000-2015 and Nikkei225 2000-2015

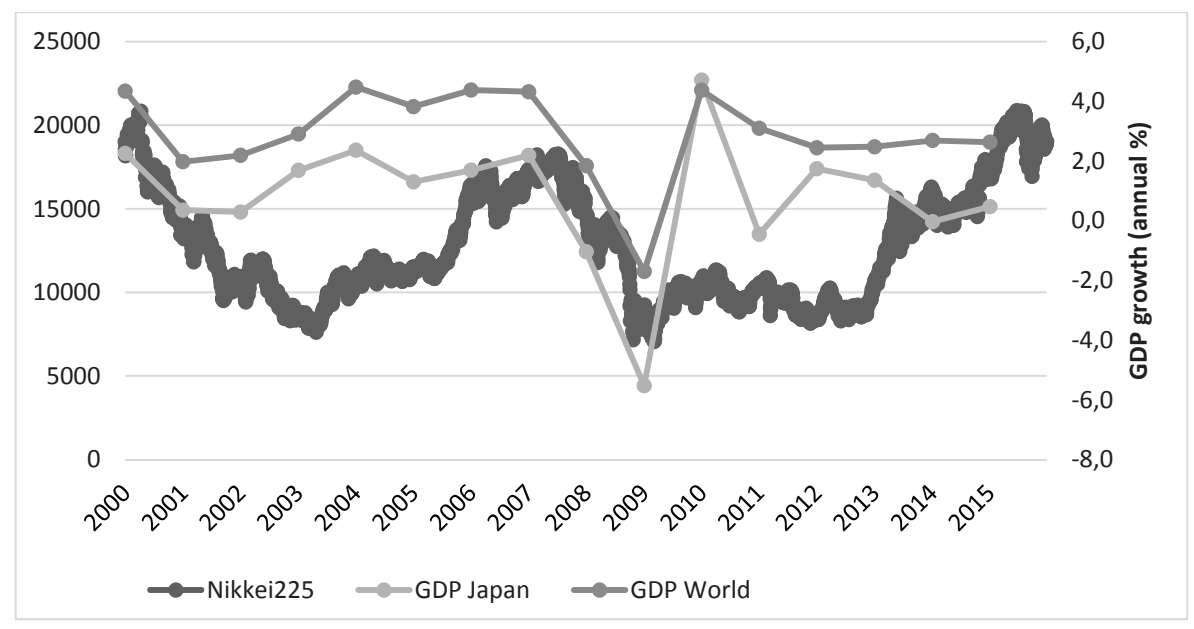

S o u r c e : own work based on: World Bank Open Data, 2016.

Figure 3. Number of sustainability reports submitted to GRI

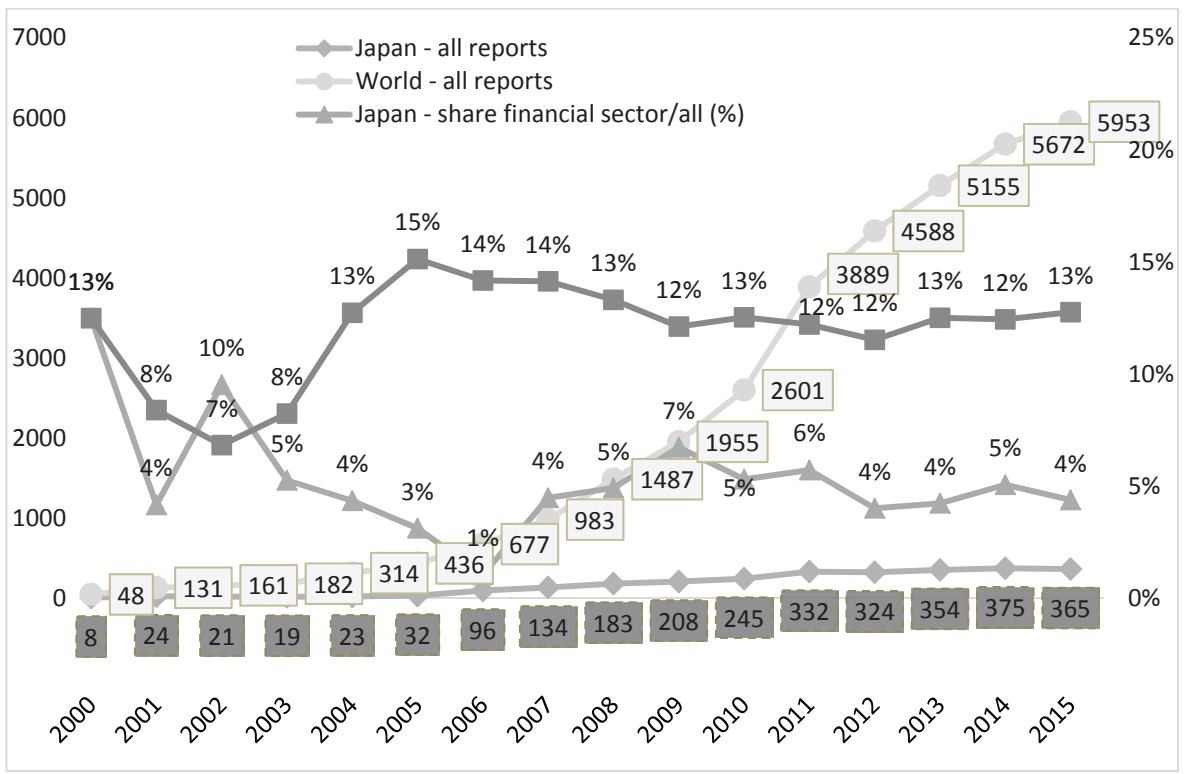

S o u r c e : own work based on: World Bank Open Data, 2016. 
However, the comparison of GDP growth, Nikkei225 (Figure 3) and number of sustainability reports (Figure 3) during the same period enables evolve the thesis that turbulences on the market do not have signs of coincidences. CSR reporting is a means for organizations to show their commitment to transparency, sustainability and their progress towards goals. The reporting process is one of most important elements in enterprise. It serves both decision makers as well as current and potential shareholders. CSR reporting helping to monitor companies' contributions to sustainable development.

\section{CONCLUSIONS}

The social responsibility of financial institutions is one of the most important issues in the modern economy. Build trust between financial markets and societies is a critical for a sustainable development. CSR initiatives are natural activities that society expects of them. Banks in Japan are highly active in the field of social business. Banks offering many products and services, e.g. eco loans or green bonds, contribute to increasing the use of renewable energy. In addition, they do not close on the environment and cooperate with local organizations. Much attention is also devoted to employees and their needs. The bank, which implements the strategies of CSR at the operational level builds relationships between the company, society and the environment. However, pointing to the positive development of banking activities should be indicated on a continuous evolution that is taking place in the banking sector. A sector that is becoming more green and responsible.

Previous analysis shows that not exists a long-term impact of the turbulences on market on activity in CSR reporting. Reporting trends are one of main discussed topics. Contemporary legislation and business practice make the annual CR reports a good practice and, increasingly duty. However, current trends show that decisions makers want to have this knowledge in real time.

\section{REFERENCES}

Banks in Japan (2016), Banks around the World. Banks in Japan, http://www.relbanks. com/asia/japan (accessed: 25.11.2016).

BoJ Annual Review (2016), Bank of Japan Annual Review 2016 Year Ended March 31, 2016. Our policy and operations, http://www.boj.or.jp/en/about/activities/act/ data/ar2016.pdf (accessed: 25.11.2016). 
Dziawgo, L. (2014). Greening financial market. Copernican Journal of Finance \& Accounting, 3(2), 9-23. http://dx.doi.org/10.12775/CJFA.2014.014.

Financial Services Agency (2016), The List of Licensed Financial Institutions, http:// www.fsa.go.jp/en/ (accessed: 25.11.2016).

GRI Research data (2016), http://database.globalreporting.org/search (accessed: 25.11.2016).

https://stooq.com/q/?s=\%5Enkx (accessed: 14.01.2017).

Japan's Policy for CSR (2012), Ministry of Economy, Trade and Industry, April 17th 2012, www.oecd.org/investment/mne/csrpolicyinjapan.pdf (accessed: 24.11.2016).

KPMG (2015), The KPMG Survey of Corporate Responsibility Reporting 2015, https:// www.kpmg.com/CN/en/IssuesAndInsights/ArticlesPublications/Documents/kpmg-survey-of-corporate-responsibility-reporting-2015-0-201511.pdf (accessed: 25.11.2016).

KPMG (2016), Corporate responsibility reporting in the Banking sector. Key findings from the KPMG Survey of Corporate Responsibility Reporting 2015, July 2016, https://assets.kpmg.com/content/dam/kpmg/xx/pdf/2016/08/corporate-responsibility-banking-sector.pdf (accessed: 25.11.2016).

Miklaszewska, E. (2012). Restrukturyzacja pokryzysowa banków. Lekcja z doświadczeń japońskich. Zeszyty Naukowe Polskie Towarzystwo Ekonomiczne, 13, 149-159.

MUFG (2016a), Mitsubishi UFJ Financial Group, Inc., MUFG Report 2016. Integrated Report, http://www.mufg.jp/english/ir2016/pdf/all.pdf (accessed: 26.11.2016).

MUFG (2016b), Mitsubishi UFJ Financial Group Green Bond, Framework overview and second opinion by sustainalytics, September $1^{\text {st }}, 2016$, http://www.mufg.jp/english/ csr/juten/sustainability/greenbond/pdf/Sustainalytics'_opinion_en.pdf (accessed: 26.11.2016).

Murawski, T. (2009). Społeczna odpowiedzialność biznesu - znaczenie i funkcje dla bankowości. In L. Pawłowicz, M. Czerwińska (Ed.), Społeczno-ekonomiczne wymiary globalnego kryzysu finansowego: (pp. 139-147). Sopot: Prace i Materiały Wydziału Zarządzania Uniwersytetu Gdańskiego.

Protess B., Silver-Greenberg, J. (2014). Bank of Tokyo Fined for 'Misleading' New York Regulator on Iran, New York Times DealBook, November 18. 2014, http://dealbook.nytimes.com/2014/11/18/lawsky-fines-bank-of-tokyo-mitsubishi-ufj-another-315-million/?_r=1 (accessed: 26.11.2016).

SMFG (2015), Sumito Mitsui Finanacial Group, CSR Report 2015, http://www.smfg.co.jp/ english/responsibility/report/pdf/2015/SMFG_csr15e_all.pdf (accessed: 26.11.2016).

Takahashi, T. (2009). CSR that Incorporates Local and Traditional Knowledge: The Sampo-yoshi Way. International Corporate Responsibility Series, 4, 107-118.

Trading economics (2016), Japan. Economic Forecasts. 2016-2020 Outlook, http:// www.tradingeconomics.com/japan/forecast (accessed: 25.11.2016).

Ushijima, K. (2016), Japanese Corporate Management and CSR, http://www.tokyofoundation.org/en/articles/2016/corporate-management-and-csr (accessed: 24.11.2016).

World Bank Open Data (2016), http://data.worldbank.org/indicator/ (accessed: 14.01. 2017). 
